\title{
Prevalence of antibodies against Neospora spp. and Sarcocystis neurona in donkeys from northeastern Brazil
}

\author{
Prevalência de anticorpos contra Neospora spp e Sarcocystis neurona em jumentos do nordeste do Brazil \\ Solange Maria Gennari ${ }^{1 *}$; Hilda Fátima de Jesus Pena ${ }^{1}$; David Scott Lindsay ${ }^{2}$; Marcos Gomes Lopes ${ }^{1}$; \\ Herbert Sousa Soares ${ }^{1}$; Aline Diniz Cabral ${ }^{1}$; Sérgio Netto Vitaliano ${ }^{1}$; Marcos Amaku ${ }^{3}$

\begin{abstract}
${ }^{1}$ Faculdade de Medicina Veterinária e Zootecnia, Universidade de Sáo Paulo - USP, São Paulo, SP, Brasil
${ }^{2}$ Department of Biomedical Sciences and Pathobiology, Center for Molecular Medicine and Infectious Disease, Virginia-Maryland Regional College of Veterinary Medicine, Virginia Tech, Blacksburg, VA, USA
\end{abstract} \\ ${ }^{3}$ Faculdade de Medicina, Universidade de São Paulo - USP, São Paulo, SP, Brasil
}

Received March 25, 2015

Accepted June 25, 2015

\begin{abstract}
Sarcocystis neurona and Neospora hughesi are coccidian protozoa that can cause neurological illness in horses in America. In this study we report seroprevalence of Neospora spp. and S. neurona in sera of 333 donkeys from the northeastern region of Brazil. Antibodies to Neospora spp. were detected in 2\% (7 donkeys) of 333 sera tested by the indirect fluorescent antibody test (IFAT) with a cut-off dilution of 1:40. Antibodies to S. neurona were found in 3\% (10 donkeys) of the samples tested by IFAT (cut-off $\geq 50$ ) and $21 \%$ ( 69 donkeys) by the direct agglutination test (SAT $\geq 50$ ). The SAT and IFAT results for $S$. neurona showed a poor concordance (value of Kappa=0.051). This is the first report of Neospora spp. antibodies in Brazilian donkeys and the first detection of antibodies against $S$. neurona in this animal species.
\end{abstract}

Keywords: Neospora hughesi, Neospora caninum, Sarcocystis neurona, donkey, Brazil.

\section{Resumo}

Sarcocystis neurona e Neospora hughesi são protozoários coccídios que infectam equídeos e são responsáveis por doenças neurológicas nessas espécies. Neste estudo, a soroprevalência de infecção por $S$. neurona e Neospora spp. foi determinada em amostras de 333 soros de jumentos da Região Nordeste do Brasil. Anticorpos contra Neospora spp. foram detectados em 2\% (7 jumentos) dos 333 animais examinados pela reação de imunofluorescência indireta (RIFI), com ponto de corte de 40. Anticorpos contra S. neurona foram detectados em 3\% (10 jumentos) das amostras pela RIFI (ponto de corte de 50) e em 21\% (69 jumentos) pela técnica de aglutinação direta (SAT - ponto de corte de 50). SAT e RIFI, para diagnóstico de $S$. neurona, apresentaram uma baixa concordância (Kappa =0,051). Essa é a primeira observação de anticorpos anti- $N$. caninum em jumentos brasileiros e a primeira deteç̧áo de anticorpos contra $S$. neurona nessa espécie.

Palavras-chave: Neospora hughesi, Neospora caninum, Sarcocystis neurona, jumentos, Brasil.

\section{Introduction}

Equine protozoal myeloencephalitis (EPM) is a neurological disease of horses that is caused primarily by Sarcocystis neurona and less frequently by Neospora hughesi (DUBEY et al., 2001, 2015). $N$. hughesi infection has also been reported to cause abortion in horses (PUSTERLA et al., 2014).

Horses become infected with $S$. neurona after ingesting sporocysts shed by opossums, Didelphis spp. In North America, D. virginiana is the definitive host for $S$. neurona, and in South America the opossum $D$. albiventris is a proven definitive host

*Corresponding author: Solange Maria Gennari. Faculdade de Medicina Veterinária e Zootecnia, Universidade de São Paulo - USP, Av. Prof. Orlando Marques de Paiva, 87, Cidade Universitária, CEP 05508-270, São Paulo, SP, Brasil. e-mail: sgennari@usp.br
(DUBEY et al., 2001). The definitive host for $N$. huguesi is unknown. Serologically antibodies against $N$. hughesi will cross-react with $N$. caninum antigen and antibodies to $N$. caninum will react to $N$. hughesi antigen (GONDIM et al., 2009). Sera reactive to $N$. caninum antigen in the present study were considered positive for antibodies to Neospora spp.

In Brazil, antibodies to Neospora spp. and $S$. neurona have been reported in horses (see reviews DUBEY \& SCHARES, 2011; DUBEY et al., 2015) but there is no report for these infections in donkeys.

Information regarding Neospora spp. and $S$. neurona exposure in donkeys (Equus asinus) from other countries is scarce (MACHACOVÁ et al., 2013; BLANCO et al., 2014). Donkeys 
are used traditionally for working roles, however in some parts of the world they are increasingly being used for milk production.

Here we report seroprevalence of Neospora spp. and S. neurona in donkeys from Brazil.

\section{Materials and Methods}

Serum samples were obtained from 333 donkeys (Equus asinus) from rural properties, located in the northeastern region of Brazil (Table 1). We used a convenience sampling technique and the animals included in the sample were those available at the time of the survey. All animals were from both genders and different ages, and were mainly bred for working roles. All procedures were conducted in accordance with the Animal Protocols approved by the Ethic Committee of the Faculty of Veterinary Medicine, University of São Paulo, Brazil.

The indirect fluorescent antibody test (IFAT) was used to detected antibodies against Neospora spp. and was conducted according to the method described by Dubey et al. (1988) using tachyzoites of NC-1 N. caninum isolate as antigen. Sarcocystis neurona merozoites of the SN3 isolate (GRANSTROM et al., 1992) were used as the antigen in $S$. neurona IFAT and in the direct agglutination test (SAT) for $S$. neurona. For IFAT, tachyzoites or merozoites were collected from cultures, washed in PBS $(\mathrm{NaCl} 0.142 \mathrm{M}$; $\mathrm{KCl}$ 0.003M; $\mathrm{Na}_{2} \mathrm{HPO}_{4}$ 0.008M; $\mathrm{NaH}_{2} \mathrm{PO}_{4} 0.001 \mathrm{M}, \mathrm{pH} 7.4$ ), counted with an hemocytometer to a concentration of $2 \times 10^{7} / \mathrm{mL}$, distributed in 12-well slides, air dried, fixed with methanol and stored at $-20^{\circ} \mathrm{C}$ until used. Sera were distributed on the wells, incubated at room temperature in wet chambers for $30 \mathrm{~min}$, and then the slides were soaked in PBS three times for $5 \mathrm{~min}$; after the slides were air dried, the conjugate was applied, and the slides were incubated and processed as described above. Fluorescein-labeled affinity-purified antibodies against horse IgG were used as conjugate in both IFATs. For $S$. neurona IFAT, the cut-off value was 1:40 and for $N$. caninum, 1:50. Every positive serum was retested using a twofold serial dilution. Positive and negative $S$. neurona and $N$. caninum horse samples were added in each slide. The SAT was performed according Lindsay \& Dubey (2001) with a cut-off value of 1:50. Positive and negative control sera were used to validate the results of each SAT.
The proportions of positive samples from the Brazilian states were compared for Neospora spp. and S. neurona using the Fisher's exact test $(Z A R, 2010)$ with a $P$ value $<0.05$ being significant.

\section{Results and Discussion}

The prevalence of antibodies to Neospora spp. in donkeys was 2\% (95\% CI: $0.8 \%-4.3 \%)$ and only donkeys from the states of Alagoas and Pernambuco were positive (Table 1). Occurrence of S. neurona was 21\% (95\% CI: $17 \%-26 \%$ ) by SAT (titers between 50 and 200) and 3\% (95\% CI: 1.5\%-5.5\%) by IFAT (titers between 40 and 160) and positive donkeys were found in all five analyzed States by SAT, but not in the state of Paraíba by IFAT (Table 1). Five of the 10 IFAT positive donkeys were also SAT positive. The SAT and IFAT results for $S$. neurona showed a poor agreement (value of Kappa=0.051).

In Italy, occurrence of antibodies to Neospora spp. in donkeys was $11.8 \%$ using a competitive-ELISA (MACHACOVÁ et al., 2013) and in Colombia, 11 of the 56 examined donkeys presented antibodies against Neospora spp. measured by Dot-ELISA (BLANCO et al., 2014). Due the different methodology used in the studies, comparisons between these studies and the present study are difficult to make.

The results for the comparisons between the proportions of positive animals from the Brazilian states are shown in Table 1. For $S$. neurona statistical analyzes were done using both the SAT and IFAT results. For the SAT results, significant differences $(\mathrm{P}<0.05)$ were observed for $S$. neurona prevalence between the samples from Alagoas and the samples from Pernambuco, Piauí and Rio Grande do Norte, and between the samples from Pernambuco and Piauí. No differences were found between the prevalence value and location for the IFAT results for $S$. neurona and also when antibodies to Neospora spp. were analyzed.

This is the first report of Neospora spp. antibodies in Brazilian donkeys and the first detection of antibodies against $S$. neurona in this animal species.

This is the first study related to $S$. neurona occurrence in donkeys and the prevalence of $21 \%$ (95\% CI: 17\%-26\%) by SAT found was lower than the prevalence of $36.0 \%$ to $69.6 \%$ found in Brazilian horses (DUBEY \& SCHARES, 2011; PIVOTO et al., 2014). In this study there was a poor agreement between IFAT and SAT. There is no comprehensive study of the sensitivity and

Table 1. Prevalence of antibodies to Neospora spp. and Sarcocystis neurona in donkeys from northeastern Brazilian States.

\begin{tabular}{|c|c|c|c|c|c|c|c|c|}
\hline \multirow{3}{*}{ State } & \multirow{2}{*}{\multicolumn{3}{|c|}{$\begin{array}{c}\text { Neospora spp. } \\
\text { IFAT }\end{array}$}} & \multicolumn{5}{|c|}{ Sarcocystis neurona } \\
\hline & & & & \multicolumn{3}{|c|}{ SAT } & \multicolumn{2}{|l|}{ IFAT } \\
\hline & Examined & Positive & $\%$ & Examined & Positive & $\%$ & Positive & $\%$ \\
\hline Alagoas & 74 & 3 & $4.0^{\mathrm{a}}$ & 70 & 27 & $38.6^{a}$ & 2 & $2.9^{\mathrm{a}}$ \\
\hline Paraíba & 30 & 0 & $0.0^{\mathrm{a}}$ & 30 & 6 & $20.0^{\mathrm{abc}}$ & 0 & $0.0^{\mathrm{a}}$ \\
\hline Pernambuco & 117 & 4 & $3.4^{\mathrm{a}}$ & 117 & 28 & $23.9^{\mathrm{b}}$ & 5 & $4.3^{\mathrm{a}}$ \\
\hline Piauí & 77 & 0 & $0.0^{\mathrm{a}}$ & 77 & 5 & $6.5^{c}$ & 2 & $2.6^{\mathrm{a}}$ \\
\hline Rio Grande do Norte & 35 & 0 & $0.0^{\mathrm{a}}$ & 35 & 3 & $8.6^{\mathrm{bc}}$ & 1 & $2.9^{\mathrm{a}}$ \\
\hline TOTAL & 333 & 7 & 2.0 & 329 & 69 & 21.0 & 10 & 3.0 \\
\hline
\end{tabular}

Different letter in the columns $\mathrm{P}<0.05$ (Fisher's exact test). 
specificity of the SAT in equids (DUBEY et al., 2001, 2015). Immunoblot is considered the golden test for seroprevalence studies of $S$. neurona in horses, but it is expensive and laborious. DUARTE et al. (2003) showed that IFAT could be an alternative to immunoblot for $S$. neurona antibody detection in horses, with good specificity and sensitivity. Cross-reactivity of both tests with other protozoa from donkeys is not known.

\section{Acknowledgements}

The present study was supported, in part, by funds from Conselho Nacional de Pesquisa (CNPq), Brazil. SMG and MA were supported by a fellowship from CNPq.

\section{References}

Blanco RD, Patarroyo JH, Vargas MI, Cardona JA, Araújo LS, Gomez VE. Ocorrência de anticorpos anti-Neospora spp. em jumentos (Equus asinus) no estado de Sucre - Colômbia. Arq Bras Med Vet Zootec 2014; 66(2): 450-454. http://dx.doi.org/10.1590/1678-41627002.

Duarte PC, Daft BM, Conrad PA, Packham AE, Gardner IA. Comparison of a serum indirect fluorescent antibody test with two Western blot tests for the diagnosis of equine protozoal myeloencephalitis. J Vet Diagn Invest 2003; 15(1): 8-13. http://dx.doi.org/10.1177/104063870301500103. PMid:12580288.

Dubey JP, Hattel AL, Lindsay DS, Topper MJ. Neonatal Neospora caninum infection in dogs: isolation of the causative agent and experimental transmission. J Am Vet Med Assoc 1988; 193(10): 1259-1263. PMid:3144521.

Dubey JP, Howe DK, Furr M, Saville WJ, Marsh AE, Reed SM, et al. An update on Sarcocystis neurona infection in animals and equine protozoa myeloencephalitis (EPM). Vet Parasitol 2015; 209(1-2): 1-42. http:// dx.doi.org/10.1016/j.vetpar.2015.01.026. PMid:25737052.
Dubey JP, Lindsay DS, Kerber CE, Kasai N, Pena HFJ, Gennari SM, et al. First isolation of Sarcocystis neurona from the South American opossum, Didelphis albiventris, from Brazil. Vet Parasitol 2001; 95(2-4): 295-304. http://dx.doi.org/10.1016/S0304-4017(00)00395-2. PMid:11223209.

Dubey JP, Schares G. Neosporosis in animals - the last five years. Vet Parasitol 2011; 180(1-2): 90-108. http://dx.doi.org/10.1016/j. vetpar.2011.05.031. PMid:21704458.

Gondim LFP, Lindsay DS, McAllister MM. Canine and bovine Neospora caninum control sera examined for cross-reactivity using Neospora caninum and Neospora hughesi indirect fluorescent antibody tests. J Parasitol 2009; 95(1): 86-88. http://dx.doi.org/10.1645/GE-1710.1. PMid:18613752.

Granstrom DE, Alvarez O Jr, Dubey JP, Comer PF, Williams NM. Equine protozoal myelitis in Panamanian horses and isolation of Sarcocystis neurona. J Parasitol 1992; 78(5): 909-912. http://dx.doi.org/10.2307/3283328. PMid:1403437.

Lindsay DS, Dubey JP. Direct agglutination test for the detection of antibodies to Sarcocystis neurona in experimentally infected animals. Vet Parasitol 2001; 95(2-4): 179-186. http://dx.doi.org/10.1016/S03044017(00)00389-7. PMid:11223198.

Machacová T, Bártová E, Di Loria A, Sedlák K, Guccione J, Fulgione D, et al. Seroprevalence and risk factors of Neospora spp. in donkeys from Southern Italy. Vet Parasitol 2013; 198(1-2): 201-204. http://dx.doi. org/10.1016/j.vetpar.2013.08.013. PMid:24050943.

Pivoto FL, Macêdo AG Jr, Silva MV, Ferreira FB, Silva DAO, Pompermayer E, et al. Serological status of mares in parturition and the levels of antibodies ( $\mathrm{IgG}$ ) against protozoan Family Sarcocystidae from their pre colostral foals. Vet Parasitol 2014; 199(1-2): 107-111. http://dx.doi. org/10.1016/j.vetpar.2013.10.001. PMid:24183649.

Pusterla N, Mackie S, Packham A, Conrad PA. Serological investigation of transplacental infection with Neospora hughesi and Sarcocystis neurona in broodmares. Vet J2014; 202(3): 649-650. http://dx.doi.org/10.1016/j. tvjl.2014.09.015. PMid:25438732.

Zar JH. Biostatistical analysis. Upper Saddle River: Prentice Hall; 2010. 